\title{
Assessment of Water Productivity of Soybean [Glycine max (L.) Merrill] based Cropping Systems under Vertisols in Malwa Plateau of Madhya Pradesh, India
}

\begin{abstract}
Background: In soybean growing areas, the agro-climatic conditions of mansoon season favours more to grow only soybean during kharif season even in assured irrigation water supply circumstances. But there is a magnificent opportunity to put back wheat during rabi season by adopting the diversification towards other crops which are having higher water productivity.

Methods: A field trial was conducted during rainy, winter and late winter seasons of the year 2015-16 and 2016-17 at the research farm of Krishi Vigyan Kendra, Dhar, M.P. to assess of water productivity of soybean [Glycine max (L.) Merrill] based cropping systems under Vertisols in Malwa Plateau of Madhya Pradesh, India. In 16 cropping sequences, soybean was sequenced with feasible winter crops viz. wheat, chick pea, garlic, onion, potato and garden pea with inclusion of garlic, onion in late winter and assessed in randomized block design with four replications.

Result: The maximum soybean equivalent yield (17731 kg/ha), net monetary returns ( $₹ 362170 /$ ha), profitability (4.0), consumptive use $(150.20 \mathrm{~cm} / \mathrm{ha})$ of water and productivity of water $(367.35 \mathrm{~kg} / \mathrm{ha} / \mathrm{cm})$ was recorded in crop sequence $\mathrm{T}_{15}$ - soybean (JS 93-05) potato (Kufri jyoti) - onion (AFLR) while the minimum soybean equivalent yield (4279 $\mathrm{kg} / \mathrm{ha})$, consumptive use of water $(60.09 \mathrm{~cm} / \mathrm{ha})$, water productivity $(115.17 \mathrm{~kg} / \mathrm{ha} / \mathrm{cm})$ and profitability (2.81) was noted in existing crop sequence i.e. $\mathrm{T}_{3}$ - soybean (JS 95-60) chickpea (JG-130) desi.
\end{abstract}

Key words: Consumptive use of water, Soybean based cropping sequences, Soybean equivalent yield, Water use efficiency.

\section{INTRODUCTION}

Soybean [Glycine max (L.) Merrill] is a major legume crop having two major quality characters viz. protein and oil. Soybean is known as 'miracle bean' rich in protein $(40 \%)$ and moderate in oil (18-22\%) and balanced amino acid and $20-30 \%$ extractable substance FAO (1982). It is widely grown in Madhya Pradesh, Maharashtra and Rajasthan and few pocket of Karnataka, Uttar Pradesh, Tamil Nadu and Andhra Pradesh as a sole or intercrop with pigeon pea, maize and cotton Singh et al. (2002). In India, it is grown on an area of about 11.33 million hectares, which is likely to produce more than 13.79 million tonnes with productivity $1217 \mathrm{~kg} /$ ha during the year 2019-20 (Anonymous, 2020). In order to that, Madhya Pradesh (5.60 million hectare), Maharashtra (4.04 million hectare) and Rajasthan (0.93 million hectare) constitute the major niche for the cultivation of soybean crop.

Water is a precious agro-resource of all living beings including crop. It works as solvent for nutrient elements, besides providing support for transportation of salts, sugars and solutes form one cell to another and one organ to another in the plants. It also plays a major role for photosynthesis and hydraulic processes in living plants like starch digestion. Water is a major constituent of physiologically active tissues and it is required for the maintenance of the cell turgidity. Water is also helpful in cell division, enlargement and ultimately essential in growth of plants. The availability of water as a resource for irrigation purpose in agriculture sector is now becoming most scarce.
Department of Natural Resource Management, Faculty of Agricuture, Mahatma Gandhi Chitrakoot Gramodaya Vishwa Vidyalaya, Chitrakoot, Satna-485 334, Madhya Pradesh, India.

Corresponding Author: Gabu Singh Gathiye, Mahatma Gandhi Chitrakoot Gramodaya Vishwa Vidyalaya, Chitrakoot, Satna-485 334, Madhya Pradesh, India. Email: gsgathiye@rediffmail.com

How to cite this article: Gathiye, G.S. and Kushwaha, H.S. (2022). Assessment of Water Productivity of Soybean [Glycine max (L.) Merrill] based Cropping Systems under Vertisols in Malwa Plateau of Madhya Pradesh, India. Legume Research. DOI: 10.18805/ LR-4736.

Submitted: 16-07-2021 Accepted: 02-12-2021 Online: 17-01-2022

Hence, use of irrigation water in agriculture sector now drawing the attention that every drop of water should be utilizing efficiently. The indiscriminate use of irrigation water should be minimized because it is not only resulting into reduction of crop yields but also results as wastage of such costly agro-input, deteriorates the soil-properties, besides disturbances of agro-ecological balances. Looking the above facts in mind, the scientists belong to agriculture are developing such good agricultural practices, which are suitable for increasing water use efficiency in cropping systems.

It is generally come across that soybean-chickpea cropping system is being widely accepted by the cultivators through replacing soybean-wheat cropping system by virtue 
Assessment of Water Productivity of Soybean [Glycine max (L.) Merrill] based Cropping Systems under Vertisols in Malwa...

of high market price of chickpea and less demand of irrigation water during growing period. Cultivation of chickpea in place of wheat is not gaining attraction of grower due to its quite low yielding ability. Water productivity is also known as water use efficiency which was estimated as rate of productivity of a crop or cropping system per unit area of land by using per unit quantity of given water as irrigation. Thus, water use efficiency of a particular cropping system mainly depends upon the productivity of various cropcomponents and consumptive use of water by them. At present, the whole world is facing water crises and seriously experiencing in all sectors of life including agriculture. Therefore, it is essential to evaluate the water productivity of various need based cropping sequences in central India.

\section{MATERIALS AND METHODS}

A field experiment was laid out during rainy, winter and late winter seasons of 2015-16 and 2016-17 at the research farm of Krishi Vigyan Kendra, Dhar, M.P. The soil of the experimental site was clay loam in texture, $\mathrm{pH} 7.60$ with normal electrical conductivity $(0.58 \mathrm{dS} / \mathrm{m})$ and medium organic carbon content i.e. $0.59 \%$. The experimental field was analysed and found values of major available nutrients i.e. N (236 kg/ha) low in available, $\mathrm{P}(11.60 \mathrm{~kg} / \mathrm{ha})$ medium in available and $\mathrm{K}(350 \mathrm{~kg} / \mathrm{ha})$ high in available contents. In these 16 cropping sequences, soybean was sequenced with feasible winter crops viz. wheat (Triticum aestivum and Triticum durum L.), chick pea (Cicer arietinum L.), garlic (Allium sativum L.), onion (Allium cepa L.), potato (Solanum tuberosum L.) and garden pea (Pisum sativum L.) with inclusion of garlic (Allium sativum L.), onion (Allium cepa L.) in late winter and tested in randomized block design with 4 replications.

Only soybean was grown during rainy season with two varieties i.e. JS 95-60 early duration (82-87 days) and JS 93-05 medium duration (90-95 days) under all cropping sequences. Different varieties as per their feasibility to accommodate the succeeding crop under present investigation were cultivated under different need based diversified cropping sequences. The variety used for winter crops was like wheat $(\mathrm{HI}-1544)$ aestivum, wheat $(\mathrm{HI}-8663)$ durum, chickpea (JG-130) desi, chickpea (RVKG-101) kabuli, Potato (Kufri jyoti), garden pea (Arkel) and garlic (G-282) and onion (AFLR) during late winter, respectively. Sowing of rainy, winter and late winter season crops were done on 21.06.15 and 26.06.16; 17.10.15 and 21.10.16 and 02.01.16 and 03.01.17 during two consecutive years, respectively. The recommended dose of $N: P: K(k g / h a)$ for soybean 20:80:20, wheat 120:60:40, chick pea 20:60:20, garlic 100:50:50, onion 100:75:50, potato 120:50:100 and garden pea 20:60:20 was applied. On going through the above facts, water use efficiency of 16 soybean based cropping sequences including existing soybean - wheat and soybean - chickpea systems were evaluated under present investigation. The observations of experiment were recorded as per standard procedure. The experimental data was statistically analysed given by Gomez and Gomez (1984). The differences among treatments were calculated by using ' $F$ ' test and critically differences at $5 \%$ probability.

The methods of calculation of various cropping system indices with their references are as follows:

Soybean equivalent yield (SEY): The cropping sequences were evaluated in terms of soybean-equivalent yield as suggested by Yadav and Newaj (1990).

Soybean equivalent yield $(\mathrm{kg} / \mathrm{ha})=$

$$
\frac{\text { Yield of a crop }(\mathrm{kg} / \mathrm{ha}) \times \text { Price of yield }(₹ / \mathrm{kg})}{\text { Price of soybean yield }(₹ / \mathrm{kg})}
$$

\section{Consumptive use of water}

The consumptive use of water under different treatments was computed with the help of following equation as suggested by Dastane (1972).

$$
\mathrm{Cu}=\sum_{\mathrm{k}=1}^{N}\left(\mathrm{E}_{\mathrm{p}} \times 0.8\right)+\sum_{\mathrm{i}=1}^{\mathrm{N}} \frac{\mathrm{M}_{1 i}-\mathrm{M}_{2 i}}{100} \times \mathrm{dbi} \times \mathrm{Di}+\mathrm{E}_{\mathrm{R}}
$$

Where;

$\mathrm{Cu}=$ Consumptive use of water $(\mathrm{mm})$.

$E_{p}=$ Pan evaporation value $(\mathrm{mm})$ from the USWB class $A$ pan for the interval from the date of irrigation to the date of sampling after irrigation.

$0.8=A$ constant factor used to get $E_{t}$ value by multiplying $E_{p}$ value for a given period.

$M_{1 i}=$ Moisture per cent of $i_{t h}$ layer on the date of sampling after irrigation.

$M_{2 i}=$ Moisture per cent of $i_{t h}$ - layers on the date of sampling before irrigation.

$\mathrm{db}_{\mathrm{i}}=$ Bulk density of $\mathrm{i}_{\text {th }}$ layer $\left(\mathrm{mg} / \mathrm{m}^{3}\right)$.

$D_{i}=$ Depth of $1^{\text {st }}$ layer of soil $(\mathrm{cm})$.

$E_{R}=$ Effective rainfall $(\mathrm{mm})$ if any during the period in consideration.

$\mathrm{n}=$ Number of soil layers.

$\mathrm{N}=$ Number of days from irrigation to sampling after irrigation.

Note: The values pertaining to irrigation varied depending on the crop and quantity of irrigation water used.

\section{Water use efficiency}

The water productivity is expressed in the productivity of a crop/crop-sequence per unit area with per unit quantity of water. It can also said to be water productivity (WUE). It was determined by using the formula as suggested by Dastane (1972).

Water productivity $(\mathrm{kg} / \mathrm{ha} / \mathrm{cm})=$

Soybean equivalent yields of the same crop sequence $(\mathrm{kg} / \mathrm{ha})$

Total consumptive use of water by all crop components in crop sequence $(\mathrm{cm})$

\section{RESULTS AND DISCUSSION}

Soybean equivalent yield (SEY)

The result showed that soybean equivalent yield of cropping system as a whole, soybean - potato - onion $\left(T_{15}\right)$ registered 
Assessment of Water Productivity of Soybean [Glycine max (L.) Merrill] based Cropping Systems under Vertisols in Malwa...

highest soybean equivalent yield (17731 kg/ha) among all crop sequences mainly due to top soybean equivalent yield of potato during winter along with considering good soybean equivalent yield of onion in late winter. The higher soybean equivalent yield in soybean - onion $\left(T_{14}\right)$ and soybean - garlic $\left(T_{13}\right)$ cropping sequence might be due to higher yield of onion in the sequence while minimum soybean equivalent yield was noted in existing soybean - chickpea $\left(T_{3}\right)$ cropping sequence i.e. $4279 \mathrm{~kg} / \mathrm{ha}$ (Table 1 and 2). This could be ascribed due to low yield realized from desi chickpea in the sequence. Similar results were reported by Billore et al. (2013), Gallani et al. (2013), Kumar and Kushwaha (2020), Narkhede et al. (2011) and Narolia et al. (2018).

\section{Consumptive use of water}

It is evident from both year data that the consumptive use of water was registered maximum $(42.05 \mathrm{~cm} / \mathrm{ha})$ in $\mathrm{T}_{16}{ }^{-}$ soybean - garden pea - garlic and $\mathrm{T}_{15}$-soybean - potato - onion

Table 1: Mean component yield $(q / h a)$ in different seasons under various crop sequences.

\begin{tabular}{lccccc}
\hline & \multicolumn{5}{c}{ Grain/bulb/tuber yields (kg/ha)\# } \\
\cline { 2 - 6 } Treatments & \multicolumn{3}{c}{ Rainy } & \multicolumn{3}{c}{ Winter } & Late winter \\
\cline { 2 - 6 } & $2015-16$ & $2016-17$ & $2015-16$ & $2016-17$ & $2015-16$ \\
\hline$T_{1}$ - Soybean - Wheat aestivum & 1841 & 1960 & 4583 & 4930 & - \\
$\mathrm{T}_{2}$ - Soybean - Wheat durum & 1848 & 1987 & 4940 & 5305 & - \\
$\mathrm{T}_{3}$ - Soybean - Chickpea desi & 1881 & 2011 & 1580 & 1695 & - \\
$\mathrm{T}_{4}$ - Soybean - Chickpea Kabuli & 1905 & 1903 & 1723 & 1868 & - \\
$\mathrm{T}_{5}$ - Soybean - Garlic & 1937 & 2013 & 8343 & 8475 & - \\
$\mathrm{T}_{6}$ - Soybean - Onion & 1930 & 2022 & 21400 & 22618 & - \\
$\mathrm{T}_{7}$ - Soybean - Potato - Onion & 1958 & 2078 & 17968 & 19415 & 18556 \\
$\mathrm{~T}_{8}$ - Soybean - Garden pea - Garlic & 2002 & 2046 & 1160 & 1258 & 6840 \\
$\mathrm{~T}_{9}$ - Soybean - Wheat aestivum & 2043 & 2125 & 4788 & 4773 & - \\
$\mathrm{T}_{10}$ - Soybean - Wheat durum & 2017 & 2108 & 5123 & 5173 & - \\
$\mathrm{T}_{11}$ - Soybean - Chickpea desi & 1969 & 2144 & 1690 & 1730 & - \\
$\mathrm{T}_{12}$ - Soybean - Chickpea Kabuli & 1941 & 2135 & 1865 & 1971 & - \\
$\mathrm{T}_{13}$ - Soybean - Garlic & 2004 & 2233 & 8590 & 8680 & - \\
$\mathrm{T}_{14}$ - Soybean - Onion & 2031 & 2285 & 21780 & 2285 & - \\
$\mathrm{T}_{15}$ - Soybean - Potato - Onion & 1967 & 2290 & 18250 & 19830 & - \\
$\mathrm{T}_{16}$ - Soybean - Garden pea - Garlic & 2065 & 2248 & 1230 & 1325 & - \\
\hline
\end{tabular}

Grain yields (q/ha)\# = Grain yield in soybean, wheat, seed yield in chick pea, tuber in potato, bulb yield in onion and garlic.

Table 2: Soybean equivalent yield $(\mathrm{kg} / \mathrm{ha})$ under various cropping sequences.

\begin{tabular}{|c|c|c|c|c|c|c|c|c|c|}
\hline \multirow{3}{*}{ Treatments } & \multicolumn{8}{|c|}{ Soybean equivalent yield (kg/ha) } & \multirow{3}{*}{ Pooled } \\
\hline & \multicolumn{4}{|c|}{$2015-16$} & \multicolumn{4}{|c|}{$2016-17$} & \\
\hline & Rainy & Winter & Late winter & Total & Rainy & Winter & Late winter & Total & \\
\hline $\mathrm{T}_{1}$ - Soybean - Wheat aestivum & 1841 & 2914 & - & 4755 & 1960 & 3103 & - & 5063 & 4909 \\
\hline $\mathrm{T}_{2}$ - Soybean - Wheat durum & 1848 & 3091 & - & 4939 & 1987 & 3308 & - & 5295 & 5117 \\
\hline $\mathrm{T}_{3}$ - Soybean - Chickpea desi & 1881 & 2265 & - & 4146 & 2011 & 2400 & - & 4411 & 4279 \\
\hline $\mathrm{T}_{4}$ - Soybean - Chickpea Kabuli & 1905 & 2768 & - & 4673 & 1903 & 2990 & - & 4893 & 4783 \\
\hline $\mathrm{T}_{5}$ - Soybean - Garlic & 1937 & 6180 & - & 8117 & 2013 & 6277 & - & 8290 & 8204 \\
\hline $\mathrm{T}_{6}$ - Soybean - Onion & 1930 & 7926 & - & 9856 & 2022 & 8377 & - & 10399 & 10128 \\
\hline $\mathrm{T}_{7}$ - Soybean - Potato - Onion & 1958 & 7986 & 6873 & 16817 & 2078 & 8629 & 7133 & 17840 & 17329 \\
\hline $\mathrm{T}_{8}$ - Soybean - Garden pea - Garlic & 2002 & 1719 & 5067 & 8788 & 2046 & 1863 & 5315 & 9224 & 9006 \\
\hline $\mathrm{T}_{9}$ - Soybean - Wheat aestivum & 2043 & 3091 & - & 5134 & 2125 & 3308 & - & 5433 & 5284 \\
\hline $\mathrm{T}_{10}$-Soybean - Wheat durum & 2017 & 3260 & - & 5277 & 2108 & 3480 & - & 5588 & 5433 \\
\hline $\mathrm{T}_{11}$ - Soybean - Chickpea desi & 1969 & 2350 & - & 4319 & 2144 & 2500 & - & 4644 & 4482 \\
\hline $\mathrm{T}_{12}$ - Soybean - Chickpea Kabuli & 1941 & 2850 & - & 4791 & 2135 & 3050 & - & 5185 & 4988 \\
\hline $\mathrm{T}_{13}$ - Soybean - Garlic & 2004 & 6250 & - & 8254 & 2233 & 6350 & - & 8583 & 8419 \\
\hline $\mathrm{T}_{14}-$ Soybean - Onion & 2031 & 8150 & - & 10181 & 2285 & 8520 & - & 10805 & 10493 \\
\hline $\mathrm{T}_{15}$ - Soybean - Potato - Onion & 1967 & 8082 & 7166 & 17215 & 2290 & 8629 & 7328 & 18247 & 17731 \\
\hline $\mathrm{T}_{16}$ - Soybean - Garden pea - Garlic & 2065 & 1720 & 5233 & 9018 & 2248 & 1970 & 5452 & 9670 & 9344 \\
\hline $\mathrm{SEm} \pm$ & 52 & 282 & 66 & 141 & 58 & 150 & 68 & 175 & 112 \\
\hline$C D(P=0.05)$ & 147 & 807 & 190 & 404 & 166 & 429 & 195 & 500 & 315 \\
\hline
\end{tabular}




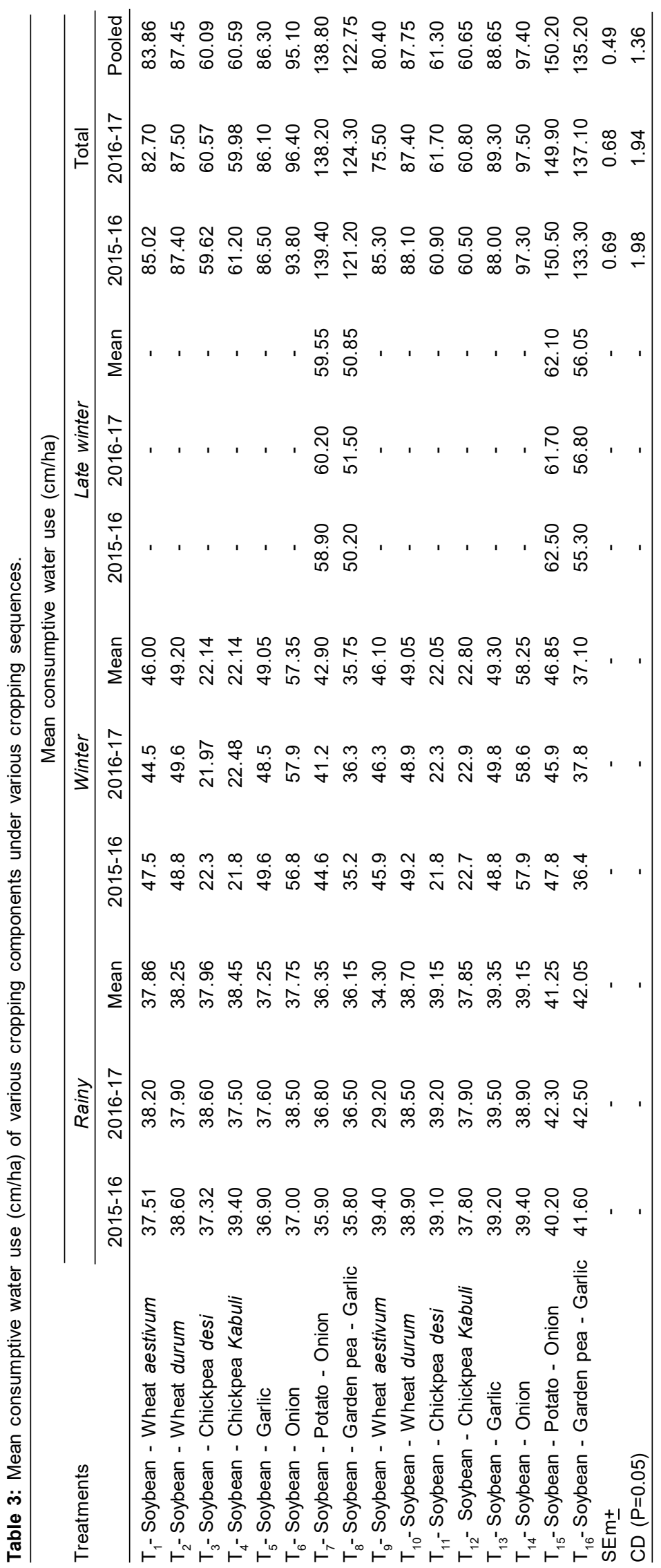




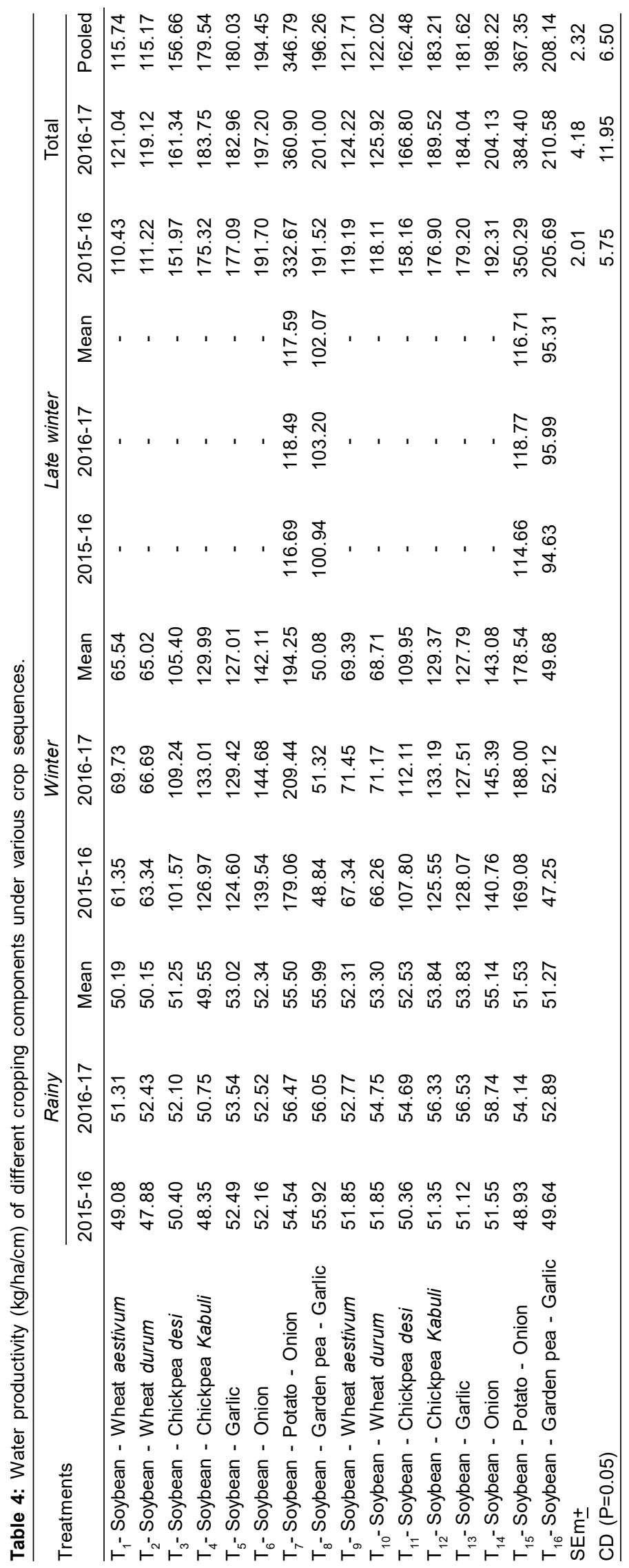


Assessment of Water Productivity of Soybean [Glycine max (L.) Merrill] based Cropping Systems under Vertisols in Malwa...

Table 5: Economics of soybean based different crop- sequences.

\begin{tabular}{|c|c|c|c|c|c|c|c|}
\hline \multirow{2}{*}{ Crop sequences } & \multirow{2}{*}{$\begin{array}{c}\text { Cost of } \\
\text { cultivation }\end{array}$} & \multicolumn{3}{|c|}{ Net monetary return (₹ /ha) } & \multicolumn{3}{|c|}{$\mathrm{B}: \mathrm{C}$ ratio } \\
\hline & & 2015-16 & $2016-17$ & Pooled & 2015-16 & $2016-17$ & Pooled \\
\hline $\mathrm{T}_{1}$ - Soybean - Wheat aestivum & 45100 & 86974 & 94009 & 90492 & 2.93 & 3.05 & 2.99 \\
\hline $\mathrm{T}_{2}$ - Soybean - Wheat durum & 45200 & 91671 & 99763 & 95717 & 3.03 & 3.19 & 3.11 \\
\hline $\mathrm{T}_{3}$-Soybean - Chickpea desi & 41500 & 73053 & 78594 & 75824 & 2.76 & 2.86 & 2.81 \\
\hline $\mathrm{T}_{4}$ - Soybean - Chickpea Kabuli & 42000 & 86128 & 93551 & 89840 & 3.05 & 3.19 & 3.12 \\
\hline $\mathrm{T}_{5}$ - Soybean - Garlic & 70700 & 149553 & 154578 & 152066 & 3.12 & 3.18 & 3.15 \\
\hline $\mathrm{T}_{6}$ - Soybean - Onion & 75200 & 192203 & 206513 & 199358 & 3.56 & 3.72 & 3.64 \\
\hline $\mathrm{T}_{7}$ - Soybean - Potato - Onion & 120900 & 333926 & 360593 & 347260 & 3.76 & 3.98 & 3.87 \\
\hline $\mathrm{T}_{8}$ - Soybean - Garden pea - Garlic & 79900 & 156703 & 169313 & 163008 & 2.96 & 3.10 & 3.03 \\
\hline $\mathrm{T}_{9}$ - Soybean - Wheat aestivum & 45100 & 95337 & 102629 & 98983 & 3.11 & 3.24 & 3.18 \\
\hline $\mathrm{T}_{10}$ - Soybean - Wheat durum & 45300 & 99934 & 107858 & 103896 & 3.21 & 3.34 & 3.27 \\
\hline $\mathrm{T}_{11}$ - Soybean - Chickpea desi & 41500 & 81416 & 87114 & 84265 & 2.96 & 3.05 & 3.01 \\
\hline $\mathrm{T}_{12}$-Soybean - Chickpea Kabuli & 42000 & 94491 & 102521 & 98506 & 3.25 & 3.39 & 3.32 \\
\hline $\mathrm{T}_{13}$ - Soybean - Garlic & 70700 & 157916 & 162673 & 160295 & 3.23 & 3.27 & 3.25 \\
\hline $\mathrm{T}_{14}$ - Soybean - Onion & 75200 & 200566 & 214558 & 207562 & 3.67 & 3.81 & 3.74 \\
\hline $\mathrm{T}_{15}$ - Soybean - Potato - Onion & 120700 & 350151 & 374188 & 362170 & 3.90 & 4.08 & 4.00 \\
\hline $\mathrm{T}_{16}$ - Soybean - Garden pea - Garlic & 80000 & 169466 & 178858 & 174162 & 3.12 & 3.15 & 3.13 \\
\hline SEm \pm & 230 & 1653 & 2951 & 1691 & 0.04 & 0.04 & 0.03 \\
\hline$C D(P=0.05)$ & 658 & 4724 & 8434 & 4736 & 0.10 & 0.13 & 0.08 \\
\hline
\end{tabular}

Value of soybean, wheat, chick pea (desi), chick pea (kabuli), garlic, onion, potato, garden pea is ₹ 2700, 1500, 3500, 4000, 2000, 1000, 1200,4000 respectively and value of straw of soybean, wheat and chick pea was ₹ 180 , ₹ 150 and ₹ 250 respectively. (Values on the basis of market price during 2016-17).

$41.25 \mathrm{~cm} /$ ha respectively during rainy season. In winter season, onion grown after soybean $\left(T_{14}\right)$ recorded maximum consumptive use of water $(58.25 \mathrm{~cm} / \mathrm{ha})$. In late winter, onion had registered maximum consumptive use of water $(62.10$ $\mathrm{cm} / \mathrm{ha}$ ). While considering the consumptive water use of an individual cropping system as a whole, soybean - potato onion $\left(T_{15}\right)$ cropping sequence recorded maximum consumptive water use $(150.20 \mathrm{~cm} / \mathrm{ha})$ closely followed by $\mathrm{T}_{16}$ - soybean - garden pea - garlic $(135.20 \mathrm{~cm} / \mathrm{ha})$ respectively over existing soybean - chickpea $\left(\mathrm{T}_{3}\right)$ cropping system (Table 3). Similar finding was reported by Billore et al. (2013), Kumar and Kushwaha (2020) and Narolia et al. (2018).

\section{Water use efficiency}

While considering, the water use efficiency of different cropping sequences as a whole, soybean - potato - onion $\left(T_{15}\right)$ registered maximum water use efficiency $(367.35 \mathrm{~kg} /$ $\mathrm{ha} / \mathrm{cm})$ as compared to existing $\mathrm{T}_{1}$ - soybean - wheat $(115.74$ $\mathrm{kg} / \mathrm{ha} / \mathrm{cm}$ ) cropping sequence (Table 4 ). Inclusion of garlic and onion during late winter in different soybean based cropping systems helped to achieve the considerable water use efficiency of different diversified intensive cropping system. Similar finding was reported by Billore et al. (2013), Kumar and Kushwaha (2020) and Narolia et al. (2018).

\section{Economics (Profitability)}

Results revealed that soybean - potato - onion $\left(T_{15}\right)$ sequence needed maximum investment ( $₹ 1,20,900)$ for growing every component of crops because of highest cropping intensity $(300 \%)$ than the prevailing cropping sequences viz. soybean-wheat ( $₹ 45,100 /$ ha) and soybean - chickpea (₹ 41,500/ha) systems. Soybean - potato - onion $\left(T_{15}\right)$ system registered maximum net monetary returns of ₹ $3,62,170 /$ ha and profitability (4.0) among all crop sequences mainly due to high production potential of entire cropping system (Table 5) than existing cropping sequences viz. $\mathrm{T}_{1}$ soybean - wheat (2.99) and $\mathrm{T}_{3}$ - Soybean - Chickpea (2.81). Similar results were reported by Billore et al. (2013), Gallani et al. (2013), Kumar and Kushwaha (2020), Narkhede et al. (2011) and Narolia et al. (2018).

\section{CONCLUSION}

It is concluded that the maximum soybean equivalent yield (17731 kg/ha), net monetary returns of $₹ 3,62,170 / \mathrm{ha}$, profitability (4.0), water consumptive use $(150.20 \mathrm{~cm} / \mathrm{ha})$ and water use efficiency $(367.35 \mathrm{~kg} / \mathrm{ha} / \mathrm{cm})$ was recorded in crop sequence soybean - potato - onion $\left(T_{15}\right)$ among all crop sequences mainly due to high production potential of entire cropping system whereas, the minimum soybean-equivalent yield $(4279 \mathrm{~kg} / \mathrm{ha})$, consumptive use of water $(60.09 \mathrm{~cm} / \mathrm{ha})$ and water use efficiency $(115.17 \mathrm{~kg} / \mathrm{ha} / \mathrm{cm})$ was noted in existing soybean - chickpea $\left(\mathrm{T}_{3}\right)$. The results revealed that there is ample scope to intensify the existing cropping sequence with inclusion of onion and garlic during late winter.

Based upon above facts, the farmers have choice to select any suitable cropping system depending on their investment capacity. 


\section{REFERENCES}

Anonymous (2020). Agricultural Statistics at a Glance, DAC, Government of India. page no. 74

Billore, S.D., Joshi, O.P, Ramesh, A. and Vyas, A.K. (2013). Productivity, sustainability and stability of soybean based cropping systems under different tillage systems. Soybean Research. 11(1): 43-57.

Dastane, N.G. (1972). Practical Mannual for Water use Research in Agriculture $2^{\text {nd }}$ Edn. Nav Bharat Prakashan, Poona, New Delhi.

FAO. (1982). Plant protection and production. Paper 4: 1-208.

Gallani, R., Sharma, S.K., Sirothia, P. and Joshi, O.P. (2013). Feasibility of organic farming system under soybeanwheat cropping sequence in Malwa region of Western Madhya Pradesh. Soybean Research. 11(2): 62-69.

Gomez, K.A. and Gomez, A.A. (1984). Statistical Procedures for Agricultural Research (2ed.). John wiley and sons, New York, 680.

Kumar, Sanjay and Kuswaha, H.S. (2020). Diversification of soybean based cropping systems under Vertisols in Malwa Plateau of Madhya Pradesh. Ph.D. Thesis (Agronomy), MGCGV, Chitrakoot, Satna, M.P.
Narkhede, W.N., Deshmukh, M.S., Bhale, VM, Gill, M.S., Gadade, G.D. and More, S.S. (2011). Diversification of cropping systems under assured irrigation conditions in central plateau zone of Maharashtra. Indian Journal of Agronomy. 56(2): 104-108.

Narolia, R.S., Meena, D.S., Meena, H.P., Singh, P. and Nagar, B.L. (2018). Productivity, Profitability and Sustainability of Soybean (Glycine max)-wheat (Triticum aestivum) cropping system as influenced by improved water management technology in South Eastern Rajasthan. Soybean Research. 16(1 and 2): 25-33.

Prajapat, K., Vyas, A.K. and Shiva, D. (2014). Productivity, profitability and land use efficiency of soybean (Glycine max)-based cropping systems under different nutrient management practices. Indian Journal of Agronomy. 59(2): 229-234.

Singh, D., Singh, H. and Ram, S. (2002). Impact of sowing dates, plant densities and farmyard manure on productivity of soybean (Glycine max). Extended Summaries $2^{\text {nd }}$ International Agronomy Congress, Nov. 26- 30, New Delhi 1: 446-47.

Yadav, D.S. and Newaj, R. (1990). Studies on increasing the utilization of natutral resources through intensive cropping systems. Indian Journal of Agronomy. 35(1 and 2): 50-55. 